\title{
Por uma teologia ficcional: a (des)construção teológica na reescritura bíblica de José Saramago
}

\author{
Orientadora: Maria Clara Lucchetti Bingemer \\ Doutorando: Márcio Cappelli Alo Lopes \\ Área de Concentração: Teologia Sistemático-Pastoral
}

Linha de Pesquisa: Religião e Modernidade

Projeto de Pesquisa: Literatura contemporânea e pensamento teológico

O presente trabalho tem como objetivo evidenciar, sobretudo, nos romances O Evangelho segundo Jesus Cristo e Caim o que nomeamos de teologia ficcional de José Saramago e como ela liga-se à temas da reflexão teológica. Inicialmente, é preciso percorrer um caminho que torne possível afirmar a literatura como autêntica expressão teológica mesmo em formato não teórico. Assim, discute-se a relação entre os dois saberes na história, aproximações e distanciamentos. No entanto, verifica-se a necessidade de afunilar a discussão em torno da ficção romanesca buscando demonstrar o seu potencial teológico. Com este pano de fundo, adentra-se o universo saramaguiano procurando desvendar como se dá a sua construção. Tendo o ateísmo declarado do autor como pressuposto influente na escrita dos romances, percebe-se como ele usa a Bíblia e carnavalizando-a desloca as afirmações do sentido tradicional operando uma verdadeira construção teológica desconstrutiva. Seguindo este percurso, são destacados, especialmente nos romances chamados bíblicos, o conteúdo da teologia ficcional saramaguiana que, mesmo diferindo da reflexão teológica, relaciona-se com ela, na medida em que, revê questões que a interessam.

Palavras-chave: Teologia e Literatura. Teologia ficcional. 